\title{
Peningkatan Daya Saing Masyarakat: Pelatihan Membatik Kreatif Ramah Lingkungan di Masa Pandemi
}

\author{
Ariesa Pandanwangi*1, Belinda Sukapura Dewi ${ }^{2} \mathrm{Ida}^{3}$, Doro Edi ${ }^{4}$, Olga Pattipawaej \\ $1,2,3,4,5$ Universitas Kristen Maranatha \\ 1,2Program Studi Seni Rupa Murni, Fakultas Seni Rupa dan Desain, Universitas Kristen Maranatha \\ ${ }^{3}$ Program Studi Manajemen, Fakultas Ekonomi, Universitas Kristen Maranatha \\ ${ }^{4}$ Program Studi Sistem Informasi, Fakultas Teknologi Informasi, Universitas Kristen Maranatha \\ ${ }^{5}$ Program Studi Teknik Sipil, Fakultas Teknik, Universitas Kristen Maranatha \\ *e-mail: ariesa.pandanwangi@ maranatha.edu ${ }^{1}$, belinda.s.dewi@ gmail.com² ${ }^{2}$ hui ie76@yahoo.com ${ }^{3}$, \\ doro.edi@it.maranatha.edu ${ }^{4}$ olga.pattipawaej@gmail.com ${ }^{5}$
}

Received: 12 Januari 2021; Revised: 26 Februari 2021; Accepted: 28 April 2021

DOI: http://dx.doi.org/10.37905/aksara.7.2.439-448.2021

\begin{abstract}
The implementation of this community service is based on a request from the Maleo South Tangerang Open Middle School to train teachers and students. They are prepared so that their graduates can increase the competitiveness of society. Based on these facts, it is important to do dedication by providing basic training in creative batik with four techniques, namely wet on wet, wet on dry, dabbing technique, and salting technique to overcome problems faced by partners. This activity is carried out in one day with 2 activity sessions. In the first session, participants were given material on how to process the Klungsu seed material. Participants are given pretest and post-test sheets to assess an increase in participants' knowledge transfer after delivering the material. In the second session the participants practiced how to make creative batik using processed klungsu seeds and 4 coloring techniques. Based on the participants' pretest-post-test scores, The Wilcoxon test results showed that there was an increase in participants' knowledge after practice how to make creative batik.
\end{abstract}

Keywords: creative batik, cold wax, ecogreen, klungsu seeds.

\begin{abstract}
Abstrak
Pelaksanaan pengabdian masyarakat ini berdasarkan permintaan dari pihak SMP Terbuka Maleo Tangerang Selatan untuk melatih guru dan siswanya. Mereka dipersiapkan agar lulusannya dapat meningkatkan daya saing masyarakat. Berdasarkan fakta tersebut, penting dilakukan pengabdian dengan cara memberikan pelatihan dasar membatik kreatif dengan empat teknik yaitu wet on wet, wet on dry, teknik colet, dan teknik penggaraman untuk mengatasai masalah yang dihadapi mitra. Kegiatan ini dilakukan dalam satu hari dengan 2 sesi kegiatan. Sesi pertama, peserta diberikan materi tentang cara mengolah material biji klungsu. Peserta diberikan lembar pretest dan post-test untuk menilai adanya peningkatan alih pengetahuan peserta setelah penyampaian materi tersebut. Sesi kedua peserta melakukan praktik cara membuat batik kreatif dengan menggunakan olahan biji klungsu dan 4 teknik pewarnaan. Berdasarkan nilai pretest-post-test peserta diketahui dengan hasil pengujian Wilcoxon menunjukkan bahwa terjadi peningkatan pengetahuan peserta sesudah kegiatan pelatihan membuat batik kreatif.
\end{abstract}

\section{PENDAHULUAN}

Masa pandemi telah membuat banyak warga memiliki keterbatasan gerak, mobilitas, dan imbasnya banyak yang kehilangan pekerjaannya (Dhawan, 2020). Kini pada era new normal banyak pihak yang berinisiatif untuk dapat menggerakkan ekonomi rakyat (Pandanwangi et al., 
2019). Salah satunya adalah pembina TKBM, PKBM Maleo, dan SMP Terbuka Maleo Tangerang yang terletak di JL. Riau Kp. Rawa Timur Pondok Pucung, Kec. Pondok Aren, Kota Tangerang Selatan Prov. Banten. Sekolah ini memiliki siswa yang berasal dari ekonomi lemah, sebagian siswanya juga berdagang makanan untuk menunjang perekonomian keluarga serta berupaya mencukupi kebutuhan sekolahnya. Siswa yang dapat diterima di Maleo betul betul disaring dan latar belakang keluarganya harus diketahui oleh pengelola sekolahnya. Sehingga hanya benarbenar murid yang kurang mampu yang dapat bersekolah di Maleo. Mereka mendapatkan fasilitas untuk belajar termasuk diberikan makan siang. Total biaya yang diberikan kepada siswa adalah gratis untuk seluruh pengeluaran. Guru-gurunya adalah para sukarelawan yang memiliki kebesaran hati untuk memajukan anak didik. Fasilitas sekolah yang berupa sarana prasarana juga merupakan donasi dari para dermawan.

Pembina Sekolah, Hj Tuty Subianto berinisiatif mengajukan permohonan kepada Ikatan kekeluargaan perempuan Maranatha (IKPM) untuk melatih para murid dan gurunya. Berdasarkan ajuan inilah IKPM memberikan pelatihan kepada mereka.

Tujuan kegiatan PkM, untuk 1) memberikan layanan pengabdian masyarakat yang memberikan penguatan dan kesadaran serta kepedulian terhadap lingkungan yang go green melalui pelatihan batik dengan media biji klungsu, 2) mensosialisasikan kearifan lokal Indonesia kepada publik, 3) meningkatkan kompetensi siswa dalam life skill, 4) alih pengetahuan tentang material lilin dingin yang ramah lingkungan 5) mengembangkan potensi wilayah.

Adapun materi yang diberikan adalah pelatihan batik dengan media lilin dingin. Media lilin dingin ini diracik dari bubuk asam jawa yang diolah sedemikian rupa sehingga menyerupai lilin panas yang difungsikan sebagai perintang dalam membatik (Dwi Ratnasari, 2017). Material lilin dingin ini diolah dari material lokal biji asam jawa (klungsu) sehingga material ini ramah lingkungan dan tidak merusak alam (Hendrawati et al., 2013). Biji asam dipilih karena memiliki sifat koagulan alami (biokoagulan) yaitu semacam senyawa kimia penggumpal (Mahardika et al., 2020), ketika bubuk biji asam jawa dituang air panas untuk diolah terbukti menggumpal dan harus dituang dengan air dingin hingga kalis dan siap dipakai sebagai lilin dingin.

Permasalahan dalam pengabdian ini adalah sekelompok masyarakat membutuhkan keahlian untuk peningkatan daya saing masyarakat. Solusi yang diberikan berupa pelatihan kepada peserta batik lilin dingin sehingga diharapkan ke depannya mereka dapat memberikan edukasi dan keterampilan sehingga dapat meningkatkan ekonomi rakyat dan menciptakan masyarakat yang memiliki daya saing tinggi (Wardoyo, 2018). Berdasarkan hasil wawancara dengan ibu Hj Tuty selaku Pembina Sekolah Maleo, peserta yang mengikuti kegiatan pelatihan ini merupakan peserta yang dipilih dan mewakili rekan rekannya, kemampuan mereka dalam bidang eksata tidak menonjol tetapi dalam bidang seni sangat menonjol kreasi mereka selalu diatas rata-rata rekannya, karena itulah mereka dipilih menjadi peserta dan memiliki kewajiban untuk mensosialisasikan kembali kepada rekan rekannya setelah pandemi berlalu.

\section{Metode}

Metode yang dipergunakan dalam pengabdian ini adalah metode pendampingan dan metode praktik (Creswell, 2014). Pelaksanaan kegiatan ini dilaksanakan di aula sekolah dengan jumlah peserta sebanyak 20 orang. Mereka didampingi oleh dua orang instruktur. Untuk mengukur keberhasilan dalam pelatihan ini dilakukan pengisian kuesioner pretest terlebih dahulu kepada peserta, setelah pelatihan, peserta mengisi kuesioner kembali (kuesioner post-test) untuk mengetahui tingkat ketercapaian yang dilihat dari sisi keberhasilan alih pengetahuan terhadap material, perubahan sikap, sosial budaya, dan ekonomi masyarakat sasaran.

Sedangkan untuk mengetahui keberhasilan melalui praktik akan langsung dibahas karyakarya peserta yang telah selesai di lapangan. Keberhasilan dalam praktik dilihat dari bagaimana peserta menggunakan material dan teknis pemakaian material yang tanpa kompor pemanas dan 
canting, pewarnaan dengan empat teknis yang telah diuji cobakan dengan cara yang mudah dan menyenangkan (Pandanwangi, 2020).

Tahapan praktik dilakukan dua sesi selama 1 hari, dimulai dari pagi hari hingga sore hari. Sesi pertama diberikan materi mengenai cara mengolah biji klungsu yang berasal dari biji asam jawa. Kegiatannya dapat dilihat pada tabel 1, yaitu:

Tabel 1. Sesi 1: Alih Pengetahuan Material Ramah Lingkungan

\begin{tabular}{|l|ll|l|c|}
\hline No & \multicolumn{2}{|c|}{ Materi Pengetahuan } & \multicolumn{1}{c|}{ Instruktur } & Waktu \\
\hline 1 & Potensi Lokal Indonesia & Ariesa Pandanwangi & $09.30-09.50$ \\
\hline 2 & $\begin{array}{l}\text { Olah Material Biji Asam } \\
\text { Jawa/Klungsu }\end{array}$ & Ariesa Pandanwangi & $09.50-10.20$ \\
\hline
\end{tabular}

Sedangkan sesi kedua adalah praktik membuat batik kreatif dengan menggunakan olahan biji klungsu dari sesi pertama. Kegiatannya dapat dilihat pada tabel 2 dan tabel 3, sebagai berikut:

Tabel 2. Sesi 2: Praktik Pembuatan Batik Kreatif

\begin{tabular}{|c|c|c|c|}
\hline No & Materi Pengetahuan & Instruktur & Waktu \\
\hline 1 & Alat dan bahan yang dipergunakan & Belinda Sukapura Dewi & \multirow{5}{*}{$10.20-16.00$} \\
\hline 2 & $\begin{array}{l}\text { Demo cara membatik kreatif tanpa } \\
\text { canting dan kompor }\end{array}$ & \multirow[t]{4}{*}{$\begin{array}{l}\text { Ariesa Pandanwangi } \\
\text { Belinda Sukapura Dewi }\end{array}$} & \\
\hline 3 & Demo cara pewarnaan & & \\
\hline 4 & Proses Pelorotan; Penjemuran & & \\
\hline 5 & Pendampingan kelompok & & \\
\hline
\end{tabular}

Tabel 3. Tahapan Pembuatan batik Kreatif

\begin{tabular}{|c|l|l|}
\hline No & \multicolumn{1}{|c|}{ Tahapan } & \multicolumn{1}{|c|}{ Alat / Bahan / Proses } \\
\hline 1 & Persiapan Material & $\begin{array}{l}\text { Alat: Spanram, hekter, } \\
\text { Bahan: kain } \\
\text { Proses: kain dibentangkan ke atas spanram kemudian di } \\
\text { hekter di atas kain yang terbentang pada keempat sisi } \\
\text { spanram. }\end{array}$ \\
\hline 2 & Cara membatik kreatif & $\begin{array}{l}\text { Alat: plastik segitiga, kwas } \\
\text { Bahan: bubuk biji asam jawa, lemak nabati, air panas, } \\
\text { pewarna }\end{array}$ \\
& $\begin{array}{l}\text { Proses pembuatan lilin dingin: bubuk biji asam jawa } \\
\text { dicampur dengan lemak nabati dan air panas, aduk hingga } \\
\text { kalis. Masukan kedalam plastik segitiga. Cara } \\
\text { menggunakanna tekan plastik segitiga ke atas objek yang } \\
\text { sudah dibuat di atas kain, setelah selesai jemur hingga } \\
\text { kering. } \\
\text { Proses pembuatan warna: } \\
\text { Pewarna terdiri dari pewarna alam yang ramah lingkungan, } \\
\text { dan pewarna sintetis. Pewarna alam memiliki keunggulan } \\
\text { yaitu tidak mencemari lingkungan, mudah didapat dari } \\
\text { sekeliling kita, aman dipakai, harganya murah karena } \\
\text { material mudah didapat (Heni Irawati et al., 2020). } \\
\text { Dalam pelatihan ini digunakan warna racikan yang berasal } \\
\text { serbuk pewarna dicampur dengan air dan dapat digunakan }\end{array}$ \\
\hline
\end{tabular}




\begin{tabular}{|c|c|c|}
\hline & & $\begin{array}{l}\text { pada bahan polyester. Gunakan kwas untuk mewarnai kain } \\
\text { yang sudah diberi gutta dan dijemur kering. Fungsi gutta } \\
\text { sebagai perintang/pembatas warna agar tidak merembes ke } \\
\text { warna lainnya. }\end{array}$ \\
\hline 3 & Cara pewarnaan & $\begin{array}{l}\text { Teknik wet on wet: kain dibasahi terlebih dahulu kemudian } \\
\text { diwarnai dengan cara di kwas. Ujung kwas celupkan pada } \\
\text { warna, kudian bagian badan kwas teteskan warna lainnya, } \\
\text { maka akan didapat warna yang eksotis karena efek } \\
\text { mblobornya. } \\
\text { Teknik wet on dry: ulaskan kwas yang basah pada } \\
\text { permukaan kain yang kering. Teknik ini harus cepat karena } \\
\text { kalau batas warna kering maka tampak pewarnaan akan } \\
\text { terlihat ada guratan batas cat pewarna yang keburu kering. } \\
\text { Teknik penggaraman: taburkan garam di atas kain yang } \\
\text { masih basah oleh pewarna. Efeknya sangat menarik seperti } \\
\text { tetesan air. Apabila taburan garam halusnya banyak maka } \\
\text { akan membentuk permukaan kain seperti retakan marmer. } \\
\text { Hal ini berbeda lagi apabila menggunakan garam yang } \\
\text { kasar (Apriani \& Pandanwangi, 2020). } \\
\text { Teknik colet: coletkan pewarna yang diinginkan ke atas } \\
\text { permukaan kain yang siap diwarna. }\end{array}$ \\
\hline 4 & Cara peloroton lilin dingin & $\begin{array}{l}\text { Cuci kain yang telah kering hingga lilin dingin luruh dan } \\
\text { bersih kemudian jemur hingga kering. Selesai. }\end{array}$ \\
\hline
\end{tabular}

\section{Hasil dan Pembahasan}

Kegiatan pengabdian kepada masyarakat ini sudah disiapkan sejak bulan November dan direalisasikan pada hari Rabu, 2 Desember 2020. Bertempat di Sekolah Maleo, Jl. Palem Puri Kp. Rawa Barat. RT 04/RW.05, Pondok Pucung, Pondok Aren, Tangerang Selatan, yang sekaligus menjadi mitra dalam kegiatan pengabdian kepada masyarakat ini. Kegiatan dilaksanakan dengan protokol kesehatan yang baik, tersedia ruangan dua lantai untuk kegiatan yang berjalan. Lantai atas dipergunakan sebagai pengerjaan batik kreatif, sedangakan lantai bawah dipergunakan sebagai proses finishing dari pelorotan lilin dingin hingga penjemuran batik kreatif.

Peserta dibagi menjadi lima kelompok, dengan tetap menjaga jarak seperti yang disyaratkan oleh pemerintah. Tahapan yang dilakukan adalah sosialisasi dan praktik singkat secara langsung.

\section{Sosialisasi}

Instruktur memberikan arahan dan demo cara menggunakan material lilin dingin yang berasal dari olahan biji klungsu. Pemanfaatan limbah dari biji asam jawa ini mempunyai keunggulan, yaitu; harganya yang murah, cara mengolahnya sangat mudah, teknis pemakaiannya nyaman dan menyenangkan, yang paling penting adalah ramah lingkungan (Syarifudin \& Hamzah, 2019). Setelah memberikan materi dilanjutkan terlebih dahulu dengan sesi tanya jawab sebelum masuk ke sesi kedua. Pada sesi tanya jawab ini, beberapa pertanyaan diajukan oleh peserta terkait pemaparan materi (Subekti \& Kurniawati, 2020), tampaknya peserta sangat tertarik dengan manfaat limbah dari biji asam jawa.

\section{Praktik}

Berikut ini adalah urut-urutan praktik yang dilakukan:

1. Setelah arahan sosialisai, siswa dan guru mempraktikan dengan cara menggutta di atas kain yang sudah disiapkan oleh instrukstur. 
2. Setelah selesai, dimulai proses pengeringan, dengan cara dijemur. Matahari yang terik membantu proses pengeringan.

3. Setelah kering diberikan warna, ada dua teknik yang diberikan yaitu teknik wet on wet dan teknik wet on dry. Teknik ini mirip dengan teknik cat air. Teknik ini juga dipadukan dengan teknik membatik yang disebut dengan teknik colet. Peserta sangat antusias keingintahuannya dalam praktik. Mereka juga diberikan teknik penggaraman, caranya, ketika kain masih basah dengan warna diberikan taburan garam, taburan garam ini memberikan efek mirip dengan tetesan air. Apabila taburan garamnya banyak maka akan memberikan efek seperti retakan marmer. Kejutan-kejutan dari efek ini semakin menarik minat peserta.

4. Setelah selesai dijemur kembali, hingga betul-betul kering.

5. Proses pelorotan dengan cara dicuci bersih dalam ember tanpa menggunakan kompor ataupun bahan kimia, sehingga larutan bekas pencucian ini ramah lingkungan.

6. Jemur dan selesai.

\section{Proses Singkat}

1. Adapun proses singkat dapat dilihat pada gambar 1 sampai gambar 5 beserta dengan penjelasannya.

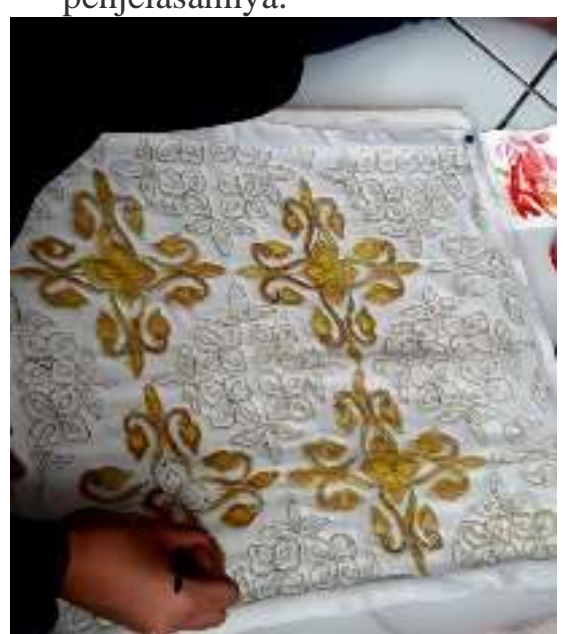

Gambar 1. Proses pemberian lilin dingin ramah lingkungan

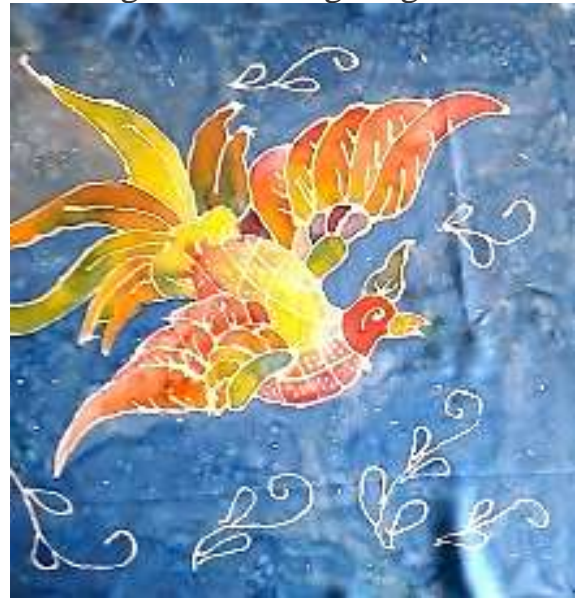

Gambar 3. Hasil pewarnaan dengan teknik penggaraman

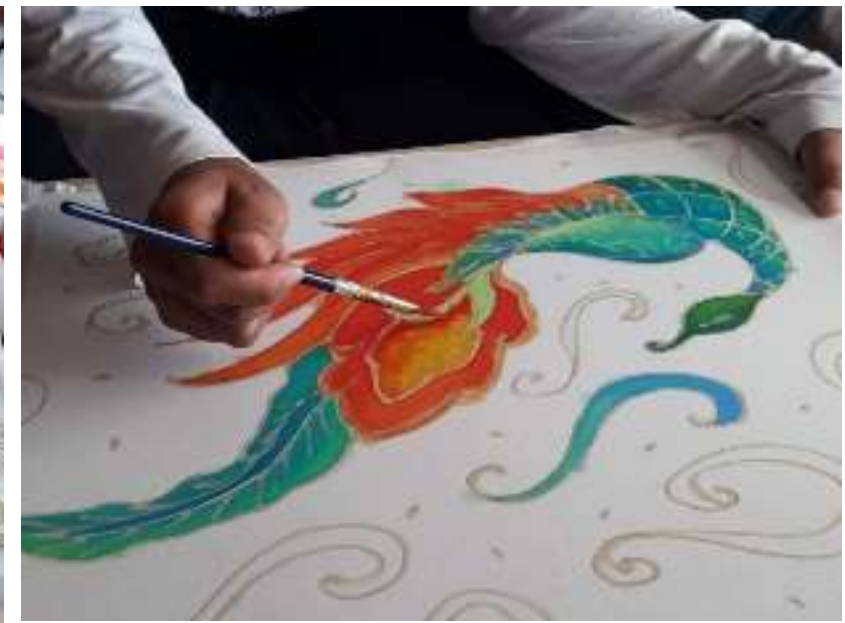

Gambar 2. Proses pewarnaan dengan teknik colet

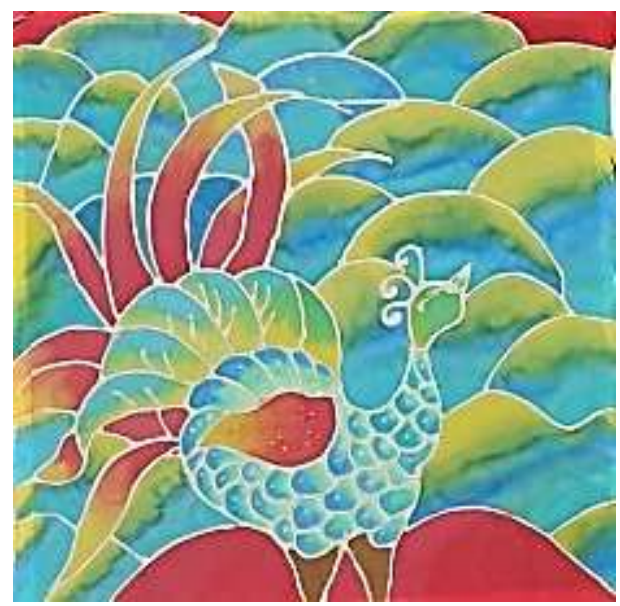

Gambar 4. Hasil pewarnaan tanpa penggaraman 


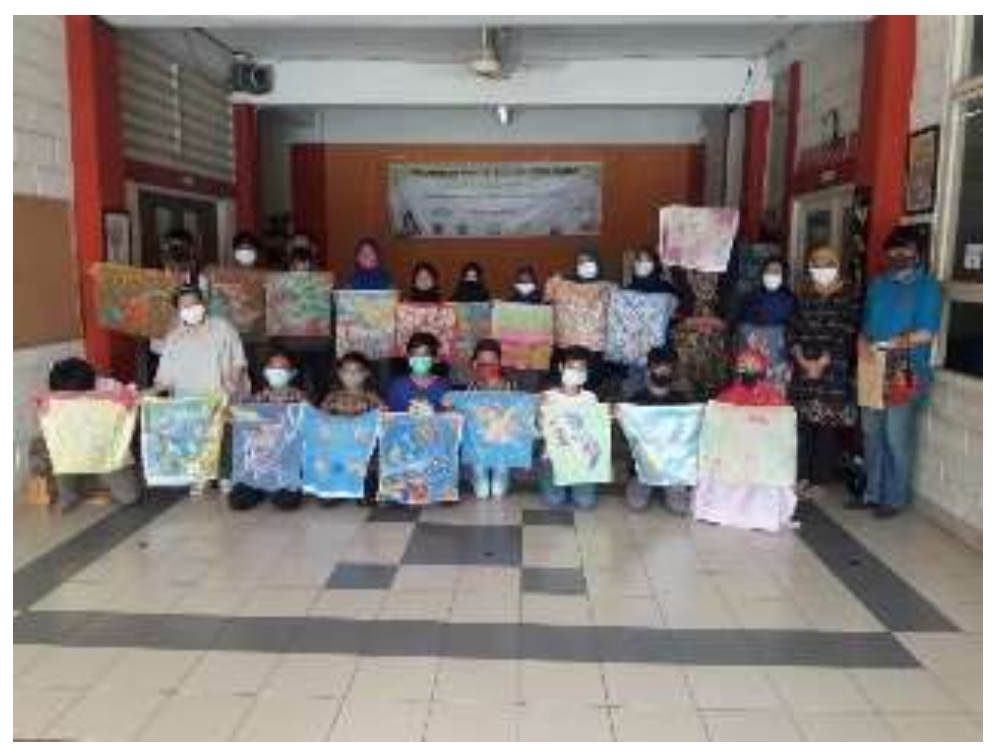

Gambar 5. Karya ke 20 peserta bersama dengan guru dan instruktur [Sumber Foto: Tim Pengabdi 2020]

Gambar 3 adalah karya dengan gambar burung sedang terbang, digambar pada bidang segi empat sama sisi, sedang burung ditempatkan dengan posisi diagonal. Kedua sayap membentang dari sudut kiri bawah dan sudut kanan kanan atas, sedangkan bagian ekor yang panjang terletak pada sudut kiri atas diagonal menempati 2/3 bagian kearah sudut kanan bawah, yang diakhiri kepala burung. Pada bagian kiri bawah sampai kanan bawah terdapat empat buah sulur bunga, sehingga bagian bawah terisi sulur sulur yang memenuhi ruang kosong dari burung tersebut. Sulur ini pun tidak hanya terdapat di daerah bawah, tetapi terdapat pula pada bagian di disebelah atas kepala dan di bagian tengah atas, secara keseluruhan sulur tersebut membentuk $3 / 4$ lingkaran. Warna latar batik berwarna biru, sedangkan warna burung dibuat warna warni, seperti ke dua helai-helai sayap menggunakan warna gradasi analogus dari kuning ke oranye. Bagian sayap kiri bawah kearah badan berwarna kuning bercampur hijau dan biru, bagian sayap kanan atas kearah badan berwarna hijau dan percampuran merah dan biru yaitu magenta serta ungu muda. Bagian dada burung berwarna pink dan bagian kepala berwarna merah, paruh berwarna kuning dan jambul di atas kepala burung berwarna hijau ke arah kuning. Punggung burung berwarna kuning mengarah ke oranye pada bagian arah ke ekor. Sedangkan ekor yang panjang berwarna kuning mengarah ke hijau pada ujung lancip dari ekor. Pada pangkal ekor terdapat bulubulu yaitu 4 helai pada samping kiri dan 2 helai pada samping kanan, adapun warna-warna yang digunakan percampuran oranye ke hijau. Burung dengan komposisi yang sangat seimbang, menguasai bidang segi empat, serta sulur-sulur bunga berwarna putih mengisi ruang kosong, sehingga membentuk kesatuan yang solid. Garis-garis organik yang dibuat pada garis-garis burung, membuat irama yang dinamis. Warna komplementer dari warna oranye burung dan latar belakang yang berwarna biru, membuat warna burung tersebut menjadi sangat kontras dan menjadi point of interest.

Teknik pemberian garam pada latar belakang batik, memberikan efek-efek berpendar dari titik-titik garam yang ditaruh pada permukaan kain basah berwarna biru tersebut memberikan efek berpendar dengan ukuran beragam tergantung dari besarnya butiran garam.

Efek dari teknik ini sangat serasi dengan teknik colet gradasi secara ekspresif, sehingga hasil dari keduanya sangat serasi, saling melengkapi.

Karya kedua (dapat dilihat pada Gambar 4), yaitu penggambaran burung merak pada bidang segi empat sama sisi. Burung digambarkan di tengah-tengah, dengan posisi tampak 
samping, sehingga bagian dari buntut merak yang sedang membuka menjadikan komposisi lebih berat ke kiri. Garis-garis fertikal dari ekor merak, mendominasi pada bagian kiri dan memotong bentuk-bentuk lengkung pada latar belakang, menjadikan gari-garis ini menjadi kontras, ditambah lagi dengan warna merah merupakan warna komplemen dengan warna hijau pada latar belakang, meskipun warna merah menjadi gradasi ke kuning pada bagian ujung, tidak membuat garis tersebut menjadi lebih lembut, tetapi warnanya lebih lembut dan membaur dengan warna yang ada pada latar belakang. Pengulangan gari-garis lengkung pada latar belakang, pangkal ekor merak maupun pada dada dan badang burung merak, memberikan irama yang dinamis dengan arah maupun bentuk yang berbeda-beda. Warna pada lengkung-lengkung latar belakang dibuat gradasi dari kuning ke hijau sehingga membentuk tiga dimensi, perbedaan besar dan kecil dari bentuk-bentuk lengkung ini memberikan kesan bergerak. Burung merak digambarkan di depan dan diperbesar sehingga menguasai ruang, burung ini dianggap penting. Kepala, jambul dan badan digambarkan tampak samping, sehingga terlihat tampak khas dari merak, sedangkan ekor digeser sehingga tampak depan supaya terlihat keindahan dari ekor merak, penggambaran aneka tampak dari burung merak. Sebaran dari warna merah di bawah, di sayap merak dan pada ekor serta di bagian atas dan sudut-sudut, memberikan kesan unity yang kuat dalam komposisi ini.

Teknik colet tanpa menggunakan garam, menghasilkan warna yang lebih merata, sesuai dengan visual yang ingin ditampilkan yaitu bentuk-bentuk lebih teratur, warna lebih terkontrol. Peran dari gutta juga sangat berpengaruh dalam membatasi warna dan pemberian warna yang kontan, gutta memberi kesan dinamis dalam menonjolkan garis-garis organik.

\section{Evaluasi}

Evaluasi kegiatan dilakukan dengan cara 20 orang peserta mengisi lembar pretest yang berisi 8 pertanyaan tentang material lokal dan cara membuat pola batik. Kemudian setelah pelatihan dan kegiatan praktik selesai, dilakukan post-test yang berisi 8 pertanyaan yang sama.

Responden yang berjumlah 20 orang terdiri dari 9 orang Laki- laki dan 11 orang perempuan, 13 orang sebagai pelajar dan 7 orang sebagai guru. Grafik peserta yang menjawab benar sebelum dan sesudah kegiatan dapat dilihat pada grafik berikut ini:

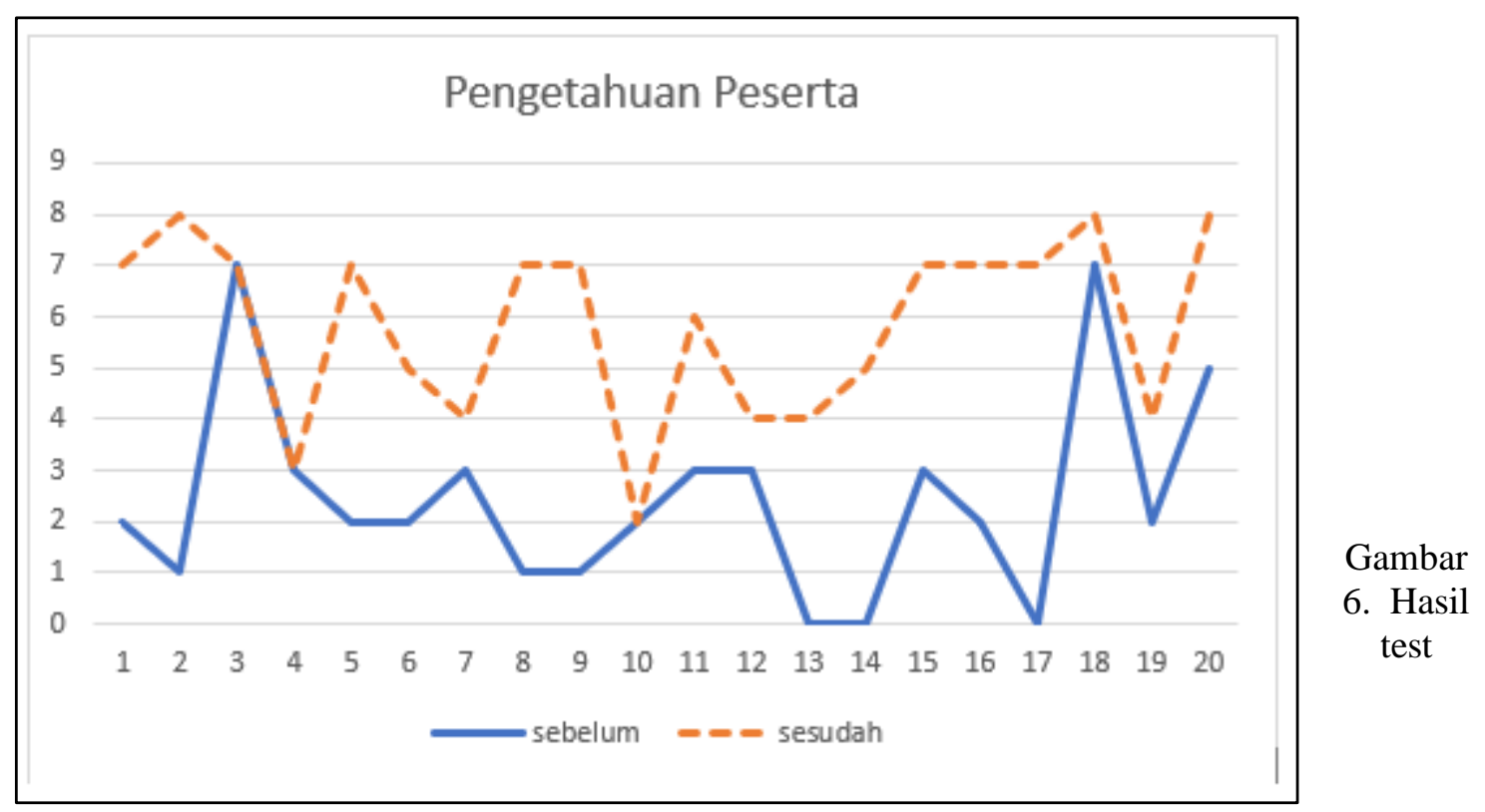

kemampuan dasar peserta pelatihan membatik kreatif yang diuji pada awal dan akhir kegiatan pengabdian. 
Lembar pretest dan post- test yang telah diisi kemudian dilakukan pengujian apakah data berdistribusi normal atau tidak. Hasil pengujian normalitas menggunakan Kolmogorov-Smirnov Test dapat dilihat pada tabel 4.

Tabel 4. Hasil Pengujian Normalitas Kolmogorov- Smirnov

\begin{tabular}{llrr}
\hline & & Sebelum & Sesudah \\
\hline $\mathrm{N}$ & & 20 & 20 \\
Normal Parameters & Mean & 2.45 & 5.85 \\
& Std. Deviation & 1.986 & 1.814 \\
Most Extreme Differences & Absolute & .241 & .287 \\
& Positive & .241 & .146 \\
& Negative & -.110 & -.287 \\
Test Statistic & & .241 & .287 \\
Asymp. Sig. (2-tailed) & & $.004^{\mathrm{c}}$ & $.000^{\mathrm{c}}$ \\
\hline
\end{tabular}

Dari hasil uji normalitas dapat dikatakan bahwa data tidak berdistribusi normal karena sig $<0.05$, maka untuk melakukan pengujian apakah terdapat peningkatan pengetahuan peserta sebelum dan setelah kegiatan dilakukan pengujian dengan uji non- parametrik yaitu Uji Wilcoxon dengan data berpasangan. Hasil pengujian Wilcoxon dapat dilihat pada tabel 5.

Tabel 5. Hasil Pengujian Wilcoxon

\begin{tabular}{lr}
\hline \multicolumn{2}{c}{ Test Statistics $^{\mathrm{a}}$} \\
\hline $\mathrm{S}$ & Sesudah - Sebelum \\
\hline $\mathrm{Z}$ & $-3.632^{\mathrm{b}}$ \\
Asymp. Sig. (2-tailed) & .000 \\
a. Wilcoxon Signed Ranks Test \\
b. Based on negative ranks. \\
\hline
\end{tabular}

Hasil pengujian Wilcoxon menunjukkan bahwa terjadi peningkatan pengetahuan peserta sesudah kegiatan pelatihan. Ini berarti tujuan pengabdian kepada masyarakat dapat dikatakan berhasil.

\section{Simpulan}

Peserta dapat dengan cepat memahami proses membuat karya dengan teknik menuangkan tamarind ke atas kain, dan mempraktikannya. Pendampingan ini dapat ditingkatkan lebih lanjut untuk membantu realisasi program pemerintah daerah dengan sebutan kampung batik. Masyarakat dapat memulai dari hal yang sederhana dengan cara berlatih dan memanfaatkan potensi lokal Indonesia. Objek yang digambarkan dapat digali dari potensi daerahnya sehingga ke depannya dapat bercirikan objek-objek khas daerah Tangerang Selatan. Ke depannya daya saing masyarakat meningkat sejalan dengan terealisasinya kampung batik.

\section{Ucapan Terima Kasih}

Tim Penulis mengucapkan terimakasih kepada Universitas Kristen Maranatha yang telah memberi dukungan financial terhadap pengabdian ini.

\section{Daftar Pustaka}

Apriani, N., \& Pandanwangi, A. (2020). Batik gutta tamarind.

Creswell, J. W. (2014). Penelitian Kualitatif dan Desain Riset. Pustaka Pelajar.

Dhawan, S. (2020). Online Learning: A Panacea in the Time of COVID-19 Crisis. Journal of Educational Technology Systems, 49(1), 5-22. https://doi.org/10.1177/0047239520934018

Dwi Ratnasari, E. (2017). Gutha Tamarin, Si Pengganti Lilin dalam Teknik Batik. CNN 
Indonesia. https://www.cnnindonesia.com/gaya-hidup/20170808171207-277233322/gutha-tamarin-si-pengganti-lilin-dalam-teknik-batik

Hendrawati, H., Syamsumarsih, D., \& Nurhasni, N. (2013). Penggunaan Biji Asam Jawa (Tamarindus indica L.) dan Biji Kecipir (Psophocarpus tetragonolobus L.) Sebagai Koagulan Alami Dalam Perbaikan Kualitas Air Tanah. Jurnal Kimia VALENSI, 3(1), 22-33. https://doi.org/10.15408/jkv.v3i1.326

Heni Irawati, Novi Luthfiyana, Imra, Triyana Wijayanti, Andi Izza Naafilah, \& Sari Wulan. (2020). Aplikasi Pewarnaan Bahan Alam Mangrove Pada Kain Batik Sebagai Diversifikasi Usaha Masyarakat. Dinamisia: Jurnal Pengabdian Kepada Masyarakat, 4(2), 285-292. https://doi.org/10.31849/dinamisia.v4i2.3982

Mahardika, R., Fitra A, Y., \& Dewi K, E. (2020). Pelatihan Lukis Batik dengan Bubur Biji Asam Untuk Guru PAUD. IKRAITH-ABDIMAS Vol, 3(1), 1-7. https://journals.upi-yai.ac.id/index.php/IKRAITH-ABDIMAS/article/view/492/360

Pandanwangi, A. (2020). Transfer of Knowledge : Educational Value in Cold Wax Batik Technique Training Keywords: In A. Rahmat \& P. Chaube (Eds.), Variety of Learning Resolutions in the Covid 19 (pp. 51-55). Novateur Publication, India. https://novateurpublication.com/index.php/np/catalog/book/11

Pandanwangi, A., Catherina, O., \& Merry, E. (2019). Pendampingan Komunitas Pembatik Melalui Pelatihan Alih Pengetahuan Membatik dengan Material Berbasis Kearifan Lokal. ENGAGEMENT: Jurnal Pengabdian Kepada Masyarakat, 3(1), 68-79. https://doi.org/http://dx.doi.org/10.29138/engagement.v3i1.89

Subekti, A. S., \& Kurniawati, L. A. (2020). Pelatihan Mendesain Pembelajaran Daring Menarik Selama Pandemi Covid-19 dengan Teknologi Pembelajaran Sederhana. Dinamisia: Jurnal Pengabdian Kepada Masyarakat, 4(4), 588-595. https://doi.org/10.31849/dinamisia.v4i4.4679

Syarifudin, H., \& Hamzah, H. (2019). Prospek Pemanfaatan Limbah Batang Pisang Dalam Mendukung Ekonomi Kreatif Masyarakat Ramah Lingkungan. Dinamisia: Jurnal Pengabdian Kepada Masyarakat, 3, 27-34. https://doi.org/10.31849/dinamisia.v3i2.2868

Wardoyo, S. (2018). Kajian Estetika Motif Batik Girilayu Kabupaten Karanganyar. Corak, 7(2), 119-128. https://doi.org/10.24821/corak.v7i2.2676 
